\title{
PERANAN TERAPI MENGGAMBAR SEBAGAI KATARSIS EMOSI ANAK
}

\author{
Oleh: \\ Muthmainnah \\ PAUD FIP Universitas Negeri Yogyakarta \\ diwan_nafil@yahoo.co.id
}

\begin{abstract}
Abstrak
Seiring dengan perkembangan dan pengalaman, anak memiliki masalah emosi yang berbeda-beda. Anak menyikapi permasalahan sesuai dengan karakteristik kepribadian masing-masing. Orang tua dan pendidik perlu membantu anakmelakukan katarsis emosi dengan menghindari perilaku destruktif, salah satunya dengan terapi menggambar. Menggambar dipilih sebagai salah satu bentuk terapi karena kegiatan ini disukai oleh anakanak sekaligus dapat membantu anak mengekspresikan pikiran dan perasaan tanpa kata-kata, serta menyalurkan isi alam bawah sadar. Tema gambar yang dipilih dapat disesuaikan dengan hal yang ingin diungkap dari anak contohnya keluargaku, cita-citaku, sahabatku, orang kusayang, kegiatan yang kusukai dan sebagainya. Melalui gambar, diharapkan orang tua dan guru dapat lebih memahami pikiran dan perasaan anak, serta membantu anak mewujudkan harapan dan menyelesaikan masalah yang dialaminya.
\end{abstract}

Kata kunci: terapi menggambar, katarsis emosi, anak

In line with their development and experience, children have various emotional problems. The way they deal with the problem is in accordance with their own personal characteristics. Parents and teachers need to help children in performing emotional catharsis by avoiding destructive behaviors. Using drawing therapy is one of the ways. Drawing is chosen as one of the therapy media because children love it and it also aids them to express their mind and feeling without having to speak a word. It also functions to expose their unconscious state. The drawing theme can be selected based on the object that is expected for them to express like 'my family', 'my dreams', 'my best friend', 'persons that I love', 'hobby', etc. Through drawing, parents and teachers are expected to understand more on the children's mind and feeling, help them accomplish their hopes and solve their problems.

Keywords: drawing therapy, emotional catharsis, children

\begin{tabular}{ll}
\hline \hline $\begin{array}{l}\text { PENDAHULUAN } \\
\text { Anak seringkali mengalami }\end{array}$ & $\begin{array}{l}\text { dimampukan } \\
\text { kesulitannya } \\
\text { tradisional/art-therapy-terobosan-dalam- } \\
\text { (http://ilmu }\end{array}$ \\
permasalahan emosional seperti cepat \\
marah, cepat tersinggung, trauma, dan \\
dunia.html). Salah satu bentuk terapi seni \\
sebagainya. Salah satu bentuk terapi yang & $\begin{array}{l}\text { adalah terapi menggambar. Menggambar } \\
\text { merupakan salah satu kegiatan yang }\end{array}$ \\
dapat diberikan adalah terapi seni.Dalam & disenangi anak. Melalui kegiatan \\
proses terapi, pasien diberi alat-alat untuk & menggambar, anak-anak dapat \\
melukis, menggambar, membentuk atau & mengekspresikan pikiran dan perasaan \\
memahat dalam rangka untuk & positif maupun negatif, mengembangkan \\
menghasilkan sebuah karya seni yang & fantasi serta kreativitasnya. Menggambar \\
kreatif, ekspresif, dan independent. & juga dapat digunakan sebagai salah satu \\
Melalui proses terapi seni, orang juga akan & bentuk terapi untuk memahami keinginan \\
merasa lebih baik, lebih kreatif, dan lebih &
\end{tabular}


dan harapan anak, mewujudkan keinginannya, serta mengatasi masalah anak.

\section{Periode Perkembangan Gambar Anak}

1. Masa mencoreng (2-4 tahun)

Anak belum mampu mengendalikan gerakan tangan sehingga haslnya tidak menentu. Goresan yang dihasilkan anak beraneka ragam berupa garis-garis panjang, garis-garis pendek yang tidak menentu arahnya dan diulangulang hingga berkembang menjadi bentuk seperti benang kusut.



Gambar 1

Sumber: google

2. Masa pra bagan (4-7 ahun)

Pada masa ini anak mulai mampu mengendalikan tangan. Garis yang dihasilkan tidak corang-coreng lagi. Anak mengambar bentuk yang berhubungan dengan dunia sekitarnya. Anak dapat membuat bentuk yang bisa dikenal meskipun kadang-kadang masih susah untu menetapkan gambar yang dibuatnya. Anak membangun ikatan emosional dengan gambar yang hendak dibuatnya.

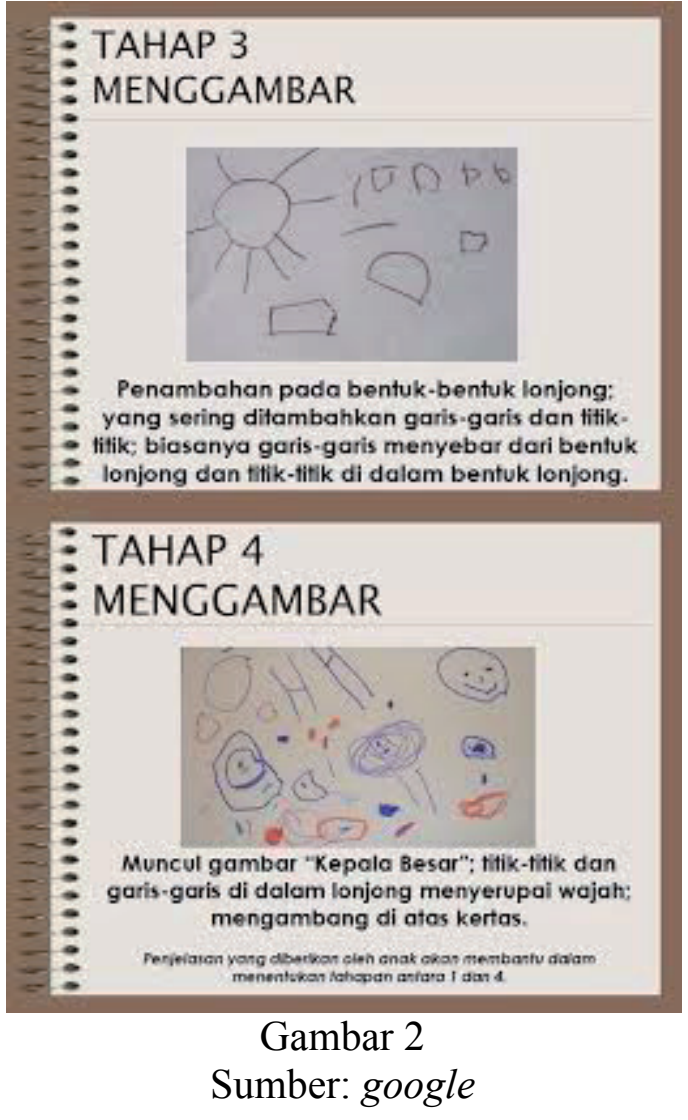

3. Masa bagan (7-9 tahun)

Pengamaatan anak bertambah teliti dan anak tahu hubungan alam sekitar dengan dirinya.

4. Masa permulaan realisme (9-11 tahun)

Masa ini ditandai dengan adanya keberadan sosial. Realisme bukan diartikan meniru alam yang tepat sebagai usaha untuk konsep visual anak-anak yang masih memandang secara subyektif, jadi gambarnya belum sesuai dengan objek.

5. Masa naturalistik (11-13 tahun)

Masa ini anak usia berpikir. Anak mulai menjadi kritis terhadap karya sendiri. Anak tidak lagi menggambar apa yang diketahui tetapi yang dilihatnya.

\section{Permasalahan Emosi Anak dan Katarsis Emosi Pada Anak \\ Anak memiliki kebutuhan emosional seperti dicintai, dihargai, merasa aman, merasa kompeten. Pada usia prasekolah anak-anak belajar menguasai dan mengekspresikan emosi. Pada tahapan}


ini anak memerlukan pengalaman pengaturan emosi, seperti mengontrol dan mengarahkan ekspresi emosional serta menjaga perilaku saat munculnya emosiemosi yang kuat. Terdapat empat gangguan emosi pada anak yaitu: ketidakmampuan untuk menunjukkan tingkah laku yang tepat dalam situasi tertentu, ketidakmampuan untuk membangun hubungan pertemanan dengan teman sebaya, mudah merasa deperesi atau cemas hanya karena alasan-alasan kecil, dan memiliki gangguan gejala tertentu saat menghadapi masalah misalnya sakit perut jika disuruh maju ke depan kelas; takut dengan semua orang dengan kumis atau berewok dan lain sebagainya (https://id.theasianparent.com/terapiemosi-untuk-anak/)

Katarsis atau katharsis, (dari bahasa Yunani: кá $\theta \alpha \rho \sigma ı \varsigma)$ pertama kali diungkapkan oleh para filsuf Yunani, yang merujuk pada upaya "pembersihan" atau "penyucian" diri, pembaruan rohani dan pelepasan diri dari ketegangan (https://id.wikipedia.org/wiki/Katarsis).

Permasalahan emosi anak tersebut dapat disalurkan atau dikatarsisikan, salah satunya melalui terapi menggambar.

\section{Terapi Menggambar}

Menggambar merupakan salah satu kegiatan yang disenangi anak-anak. Dalam kegiatan menggambar, baik menggambar ekspresi, menggambar ilustrasi maupun menggambar dekorasi dituntut penguasaaan keterampilan. Hakikat menggambar adalah penyajian ilusi optik atau manipulasi ruang dalam bidang datar dua dimensi (Muharam E dan Warti Sundaryati, 1991: 95). Menggambar merupakan kegiatan yang menyenangkan untuk mengekspresikan perasaan dan pikiran ke dalam bentuk simbol. Menggambar tidak hanya digunakan untuk mengasah keterampilan motorik halus mengembangkan imajinasi dan kreativitas, namun dapat juga digunakan sebagai bentuk terapi.
Terapi menggambar berkembang untuk membantu anak yang tidak dapat mengekspresikan pikiran dan perasaan melalui kata-kata. Gambar dapat memberikan makna jika dihubungkan dengan anak-anak yang terluka, mengasingkan diri, kecewa, dan tidak dapat mengungkapkan pikiran dan perasaan kepada orang lain (Sri Esti Wuryani,2005: 363-364). Terapi menggambar mengajak individu mengenali kejadian atau hal yang selama ini disukai atau tidak disukai. Melalui terapi menggambar, hal-hal yang ditekan dalam alam bawah sadar dapat diangkat ke alam sadar.

Terapi menggambar adalah terapi yang diberikan dengan meminta anak mengekspresikan pikiran dan perasaan yang dialmai dalam bentuk gambar. Anakanak yang berkelahi dengan anak lain mungkin dapat mengekspresikan kemarahan, kebencian, atau penolakan melalui gambar (Sri Esti Wuryani,2005: 384). Terapi menggambar dirancang untuk membantu individu mengenali suara dalam alam bawah sadar, mendorong untuk menyembuhkan jiwa melalui terapi menggambar, mereduksi pikiran dan perasaan negatif (Snyder, dalam Sri Esti Wuryani, 2005).

Anak dapat diminta menggambar apa yang sedang dipikirkannya, sehingga terapis dapat memperoleh gambaran secara visual apa yang sedang dialami dan dibutuhkan anak. Gambar merupakan media komunikasi untuk mengungkapkan apa yang diharapkan anak. Melalui gambar, anak dapat membebaskan perasaan, mengungkapkan permasalahan atau konflik, mengekspresikan pikiran dan perasaan yang barangkali belum mampu diungkapkan secara verbal. 


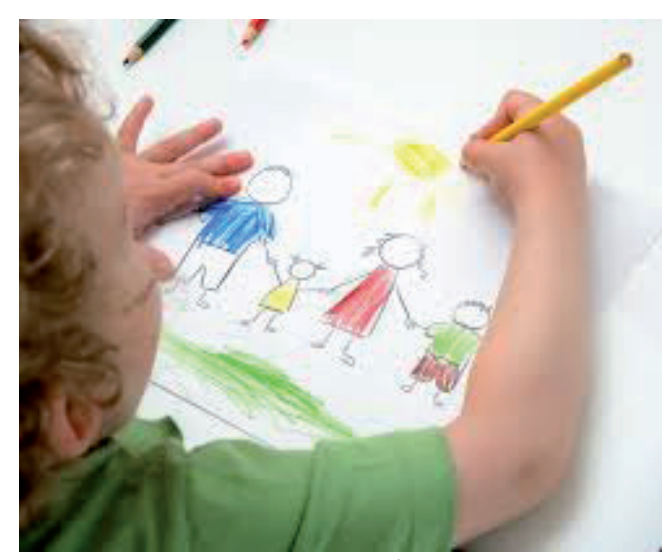

Gambar 3.

Anak menggambar tentang keluarganya (Sumber: google)

Warna merupakan sebuah media terapi bag ibanyak orang, bahkan warna dapat digunakan sebagai bahasa untuk membaca emosi seseorang. Seorang anak yang mewarnai matahari dengan warnawarna gelap seperti hitam atau abu-abu bias jadi menandakan kemarahan. Apabila anak mewarnai dengan cara menorehkan garis-garis teratur pada gambar menunjukan bahwa anak memiliki kecenderungan gaya hidup teratur. Terlepas dari itu warna sendiri menjadi alat terapi untuk meringankan stress pada anak setelah lelah seharian beraktivitas (http://blog.lazada.co.id/manfaat-belajarmenggambar-mewarnai-bagi-anak/).



Gambar 4.

Gambar anak dengan pilihan warna cerah (Sumber: google)

\section{Peranan terapi menggambar}

Anak dapat mengekspresikan perasaannya dengan cara menggambar, ini berarti menggambar bagi anak merupakan suatu cara untuk berkomunikasi tanpa menggunakan kata-kata (Suparto, 2003, dalam Paat, 2010). Kramer (Sri Esti Wuryani,2005: 366) juga menjelaskan bahwa proses mengambar dan hasilnya dapat membantu individu membebaskan konflik, mengalami kembali suatu kejadian, menyalurkan kembali melalui sublimasi, dan menyelesaikan masalah. Saat anak menggambar berarti anak mengkomunikasikan pikiran dan perasaan, menyelesaikan konflik dengan aman tanpa merasa terancam, membantu memberika gambaran bagaimana anak memandang dirinya atau peran atau posisinya dalam keluarga, membantu mengerti, mengkomunikasikan tentang masalah keluarga (Handler, dalam Sri Esti Wuryani,2005: 384). Selain itu menggambar juga dapat membantu anak mengekspresikan kemarahan, kebencian, penolakan, frustasi dan kemarahan dengan cara yang aman, membebaskan anak dari perasaan terluka karena penyiksaan, mudah meledak-ledak karena marah dan tersinggung, membebaskan anak dari rasa malu, dan menghalangi anak yang suka mengasingkan diri (Djiwandono, 2005: 365). Adapun tema yang dipilih untuk menggambar seperti acara favoritku, kejadian yang menakutkan, peristiwa yang baru saja dialami, perasaan hari ini, harapan, dan sebagainya.

\section{Peran guru}

Dalam membantu anak melakukan katarsis dengan tepat dan tidak destruktif, beberapa peran guru diantaranya:

1. Memberikan keleluasaan waktu pada anak untuk melakukan terapi.

Keleluasaan waktu diberikan dengan memberikan beberapa kesempatan anak untuk melakukan aktivitas katarsis misalnya dengan membuatbeberapa gambar untuk mendeskripsikan perasaan dan pikirannya.

2. Mampu menghubungkan gambar dengan konflik anak. 
Dari karya atau gambar yang telah dibuat anak, guru dapat mencoba menganalisis makna atau maksud gambar. Tentunya dalam menganalisis atau menghubungkan makna gambar perlu disertai dengan tanya jawab atau wawancara agar dapat memaknai sesuai yang dialami anak.

3. Memberikan dukungan dan dorongan agar tidak pernah putus asa, dan selalu percaya diri dalam berekspresi maupun berkreasi.

Guru perlu memberikan dukungan dan dorongan agar anak mampu berpikir positif dan tetap memiliki kepercayaan diri dalam mengatasi masalah yang dihadapi.

4. Terapis perlu mengamati warna, pesan dan tema dalam gambar anakanak,mendengarkan anak-anak dengansungguh-

sungguh,danmenginterprestasikan

gambar anak.

Kecermatan dalam mengamati gambar dapat membantu terapis atau pendidik dalam memaknai gambar yang dibuat anak.

\section{Interpretasi gambar}

Malchiodi (dalam Sri Esti Wuryani, 2005)menyatakan bahwa gambar berfungsi sarana komunikasi agar anak berpartisipasi dalam proses terapuetik. Karen Machover juga menemukan adanya suatu hubungan yang erat antara figur gambar dan kepribadian.Anak yang mengalami masalah emosi dan sosial sering menggambar dengan bentuk kepala yang besar.Apabila gambar wajah hilang dan bagian lain dari tubuh digambar dengan sangat hati-hati, mengindikasikan adanya kesulitan dalam hubungan dengan orang lain. Mulut yang digambarkan dengan garis sendirian mungkin mengindikasikan ketegangan, dan gambar mulu dengan goresan yang berat mengindikasikan agresif. Gambar mata yang besar dan gelap menciptakan kesan curiga.

Dalam menggambar, kadangkala anak menghilangkan dirinya sendiri dan mungkin ini menunjukkan bahwa anak kurang mempunyai persaan memiliki dalam keluarga, atau mera tidak dihargai oleh anggota keluarga (Sri Esti Wuryani,2005: 407).Gambar tangan yang saling menyentuh dan berpegangan satu sama lan mengindikasikan adanya kehangatan dan kasih sayang dalam keluarga. Gambar anggota keluarga yang tidak tersenyum dan tidak ada gambar mulut mengindikasikan kurangnya komunikasi.Posisi gambar yang lebih tinggi mengindikasikan lebih berkuasa (Sri Esti Wuryani,2005: 406).Menurut Di Leo, ketidakmampuan anak untuk menghasilkan figur manusia yang terintegrasi dicatat sebagai bentuk penyimpangan dan adanya indikasi kepribadian yang tidak terorganisir (Sri Esti Wuryani,2005: 400).

Anak yang menghapus gambar biasanya secara signifikan mengatakantentang bagaimana anak memandang diri dan hubungan dengan orang lain (Sri Esti Wuryani,2005: 398).Bentuk badan kecil menunjukkan perasaaan tidak aman, mengasingkan diri, dan merasa tidak terampil atau mampu. Bentuk badan besar menandakan adanya keterbukaan dan kontrol diri dan gambar tangan pendek menunjukkan mengasingkan diri, tangan panjang menjangkau orang lain.

\section{Langkah-langkah dalam Penerapan Terapi Menggambar}

1. Mengembangkan hubungan (rapport) Menjalin hubungan merupakan langkah awal untuk menumbuhkan kepercayaan dan kenyamanan anak atau klien pada terapis. Apabila anak sudah merasa nyaman dan dapat mempercayai terpias, maka kecenderungan anak atau klien akan lebih terbuka untuk mengungkapkan apa yang dialami.

2. Memberikan kesempatan anak menggambar

Terapis dapat memulai dengan warna karena warna memiliki simbol kuat. 
Salurkan perasaan lewat warna; pilih bentuk atau obyek dalam pikiran; teruslah menggambar hingga tak memiliki lagi apa pun dalam pikiran.

3. Mencermati dan menganalisis gambar anak

Terapis mencermati dan menganalisis gambar untuk mencari tahu makna gambar.

4. Wawancara

Wawancara dilakukan untuk menggali lebih dalam tentang apa yang dirasakan dan dipikirkan anak.

5. Anak diminta menceritakan gambar

Setelah menggambar, anak dapat diminta untuk menceritakan gambar. Namun jika anak enggan, maka terapis yang lebih aktif untuk bertanya pada anak tentang gambar yang telah dibuat anak.

6. Observasi

Observasi atau pengamatan dilakukan dengan mencermati perilaku anak.

7. Konseling

Konseling dilakukan sebagai upaya tindak lanjut untuk membantu anak menuntaskan masalahnya. Sasaran konseling tidak hanya pada anak, namun memungkinkan juga melibatkan orangtua atau pihak lain yang terkait dengan masalah anak.

\section{PENUTUP}

Sebagian anak mengalami permasalahan namun belum memiliki kemampuan untuk mengungkapkan apa yang dialaminya secara lisan. Menggambar dapat dijadikan sebagai salah satu bentuk terapi untuk membantu anak mengungkapkan pikiran dan perasaan serta menyalurkan energi emosi dengan cara yang lebih aman. Menggambar dipilih sebagai salah satu bentuk terapi karena kegiatan ini disukai oleh anak-anak sekaligus dapat membantu anak mengekspresikan pikiran dan perasaan tanpa kata-kata, serta menyalurkan isi alam bawah sadar. Tema gambar yang dipilih dapat disesuaikan dengan hal yang ingin diungkap dari anak contohnya keluargaku, cita-citaku, sahabatku, orang kusayang, kegiatan yang kusukai dan sebagainya. Melalui gambar, anak dapat mendeskripsikan dan menyalurkan emosi terpendamnya sebagai bentuk katarsis. Dari gambar yang telah dibuat, diharapkan uneg-uneg anak dapat tersalurkan secara tidak langsung, mengurangi tindakan destruktif saat muncul emosi negatif, dan akan ditindaklanjuti dengan konseling untuk menuntaskan masalahnya.

\section{DAFTAR PUSTAKA}

http://blog.lazada.co.id/manfaat-belajarmenggambar-mewarnai-bagianak.Diakses tanggal 10 Maret 2016.

http://ilmu pengobatan tradisional/arttherapy-terobosan-dalamdunia.html. Diakses tanggal 10 Maret 2016.

https://id.theasianparent.com/terapi-emosiuntuk-anak. Diakses tanggal 10 Maret 2016.

https://id.wikipedia.org/wiki/Katarsis. Diakses tanggal 10 Maret 2016.

Muharam E dan Warti Sundaryanti. (1991). Pendidikan Kesenian Seni Rupa. Jakarta: Depdikbud Dirjen Dikti.

Sumanto. (2005). Pengembangan Kreativitas Seni Rupa Anak TK. Jakarta: Depdiknas Dirjen Dikti.

Sri Esti Wuryani Djiwandono. (2005).Konseling dan Terapi dengan Anak dan Orangtua. Jakarta: Gramedia. 